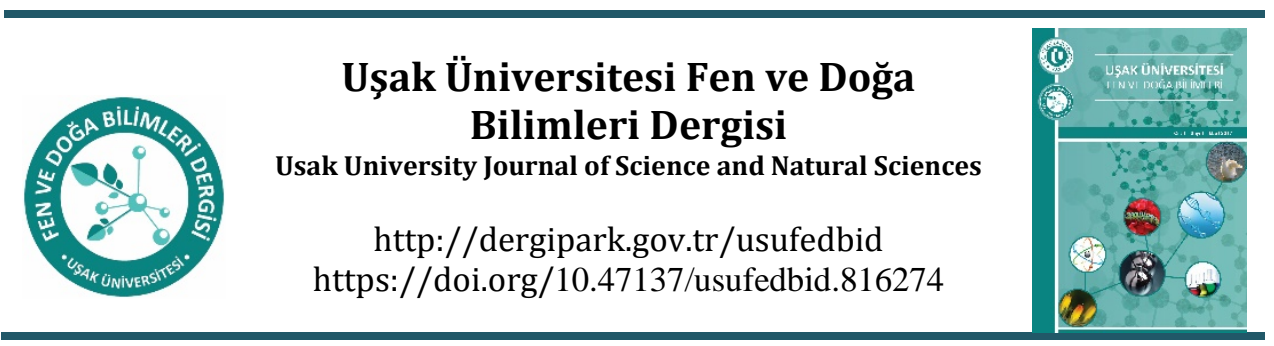

Araştırma makalesi

\title{
Hazır Yemek Sektörü Çalışanlarının İş Sağlığı ve Güvenliğine Kaderci Bakış Açılarının Değerlendirilmesi
}

\author{
Hakan Gezgel, Abdullah Dikici* \\ Gıda Mühendisliği Bölümü, Mühendislik Fakültesi, Ușak Üniversitesi, Uşak, Türkiye
}

Geliş: 27 Ekim 2020

Kabul: 27 Ocak 2021 / Received: 27 October 2020

Accepted: 27 January 2021

\begin{abstract}
In this study, the fatalistic perspectives of workers in the catering sector on occupational health and safety were investigated. Although the catering sector is an important area in terms of the food industry and the size of the number of employees, it is an area where occupational health and safety is not given sufficient importance due to the insufficient attention to occupational safety or the fact that the majority of occupational accidents that occur are simple injuries. This study was conducted as a survey with 160 people working in the catering sector in Ankara. As a result of the survey, it was concluded that the employees associate the accidents with the fatalism and this varies according to the gender and occupational health and safety knowledge level. In addition, it was observed that the participants were hesitant to provide information about the measures taken by the workplace within the scope of occupational health and safety. This study reveals that the fast food sector is underestimated in terms of occupational health and safety. It is considered that the result of the study will contribute to to the development of occupational health and safety awareness in the sector and to reduce the fatalism understanding of the employees to an acceptable level.
\end{abstract}

Keywords: Catering, occupational health and safety, mass feeding.

\section{Özet}

$\mathrm{Bu}$ çalışmada hazır yemek sektörü çalışanlarının iş̧ sağlığı ve güvenliğine kaderci bakış açıları araştırılmıştır. Hazır yemek sektörü, gıda sanayi ve çalışan sayısının büyüklüğü açısından önemli bir alan olmakla birlikte iş güvenliğine yeterince önem verilmemesi veya meydana gelen iş kazalarının büyük çoğunluğunun bireysel basit yaralanma ağırlıklı olmasından kaynaklı önemsenmemesi nedeniyle iş sağ lı̆̆ı ve güvenliği açısından yeterli önemin verilmediği bir alan olarak karşımıza çıkmaktadır. Bu çalışma, Ankara ilinde hazır yemek sektöründe çalışan 160 kişiyle yüz yüze görüşülerek anket uygulanması şeklinde yürütülmüştür. Anket sonucunda çalışanların kazaları kadercilik anlayışı ile örtüștürdüğü ve bu anlayışın cinsiyet ve iş sağlığı ve güvenliği bilgi seviyesine göre değiştiği sonucuna ulaşılmıştır. Ayrıca katılımcıların iş yerinin iş sağlığı ve güvenliği kapsamında aldığı tedbirlerle ilgili bilgi verme konusunda tereddüt ettiği görülmüştür. Yapılan bu çalışma, hazır yemek sektörünün iş sağlığı ve güvenliği açısından yeterince önemsenmediğini ortaya koymaktadır. Araştırma sonucunda elde edilen verilerin sektörde iş sağlı̆̆ı ve güvenliği bilincinin geliştirilmesine ve çalışanların kadercilik anlayışının kabul edilebilir bir seviyeye indirilmesine katkı sağlayacağı değerlendirilmektedir.

\footnotetext{
${ }^{*}$ Corresponding author: Abdullah Dikici

E-mail: a.dikici@usak.edu.tr

ORCID ID: 0000-0001-7302-8766
}

(C)2021 Usak University all rights reserved. 
Anahtar Kelimeler: Hazır yemek, iş sağlı̆̆ı ve güvenliği, toplu beslenme.

(C)2021 Usak University all rights reserved.

\section{Giriș}

İş Sağlığı ve güvenliği, ülkemizde özellikle son yıllarda önemsenmeye başlayan ve önemi günden güne giderek artan bir kavramdır. Kavramın önemi, Avrupa Birliği uyum yasalarının yanı sıra yașanan kazalar ve bu kazalardan kaynaklı mal ve can kayıpları ile bu kayıplardan kaynaklı tazminatlar nedeniyle de ön plana çıkmaktadır. Kavramın tanımına baktığımızda ise Dünya Sağlık Örgütü (WHO) ve Uluslararası Çalıșma Örgütü'ne (ILO) göre iș sağlığı ve güvenliği; "İș Sağlığı her meslekteki ișçilerin fiziksel, ruhsal ve sosyal iyiliklerini en üst düzeyde koruma ve geliștirmeyi; ișçilerin çalıșma koșullarından ötürü sağlıklarını kaybetmelerinin önlenmesini; işçilerin ișyerindeki sağlığa zararlı faktörlerden kaynaklanan risklerden korunmasını; işçinin fiziksel ve psikolojik donanıma uygun işte çalıșmasının sağlanmasını ve özetle işin insana uyarlanması ve her insanın işine adapte edilmesini amaçlar" şeklindedir [1]

İş sağlığı ve güvenliği, henüz bir tehlikeyle karşı karşıya kalınmamışken, bir işletmede ortaya çıkabilecek risk ve tehlikelerin önlenmesine veya kabul edilebilir seviyeye indirilmesine yönelik çalıșmaları kapsayan bir kavramdır [2]. Yaplan araștırmalar iş kazalarının büyük kısmının çalışanların eğitimsiz ve güvensiz davranışları nedeniyle ortaya çıktığını göstermektedir. Bu nedenledir ki -yapılan işin niteliğine göre değișmekle birlikte- insan faktörü iş kazaları açısından en önemli olanıdır. Çalışanın ruh hali ve psikolojisi, çalışma arkadaşları ile arasındaki diyalog, ihmalkâr ve hatalı davranışlar, istem dışı davranışlar, bilgi ve tecrübe eksikliği, unutkanlık gibi faktörler örnek olarak gösterilebilmektedir. Ayrıca insanla ilgili sayılan bu faktörler her gün veya günden güne değișkenlik göstermektedir ve her bir çalışan için bireysel olarak değerlendirilmelidir. Gelişen teknoloji ve yürütülen bilimsel çalışmalar neticesinde iş kazası ve meslek hastalıklarının engellenmesi veya kabul edilebilir bir seviyeye indirilmesi mümkündür [2], [3]

Ülkemizde iş sağlığı ve güvenliği ile ilgili yasal düzenleme 2003 yılında çıkarılan 4857 Sayılı İş Kanunu ile başlamış ve 2012 yılında 6331 Sayılı İş Sağlığı ve Güvenliği Kanunun yürürlüğe girmesiyle devam etmiş ve bu tarihten itibaren bu kanun kapsamında çıkarılan tebliğ, yönetmelikler doğrultusunda iş sağlığı ve güvenliği hizmetleri yürütülmektedir [4], [5].

Dünya Sağlık Örgütü (WHO)'ne göre, dünyada toplam 3 milyar çalışanın \%80'inden fazlası temel iș sağlığı hizmetlerinden yoksundur. Ayrıca Uluslararası Çalıșma Örgütü (ILO)'nün yaptığı açıklamalara göre dünyada her yıl ortalama 317 milyon iș kazası meydana gelmektedir. Ayrıca her 15 saniyede bir çalışan iş kazası sonucu yaralanmakta ve her gün 6300 kiși iș kazası veya meslek hastalıkları nedeniyle hayatını kaybetmektedir [3]. Sosyal Güvenlik Kurumu (SGK) 2018 yılı istatistiklerine göre 22.487'si iş kazası Yiyecek ve İçecek Hizmeti faaliyetleri sektöründe olmak üzere toplam 430.985 iș kazası meydana gelmiştir. Meydana gelen iş kazaları sonucunda 21 kişi Yiyecek ve İçecek Hizmeti faaliyetleri sektöründe olmak üzere toplam 1541 kişi iş kazaları meslek hastalıkları nedeniyle hayatını kaybetmiștir [6].

Hazır yemek sektörü, gıda sanayi ile ilgili imalatların birçoğu gibi İş Sağlığı ve Güvenliğine İlişkin İşyeri Tehlike Sınıfları Tebliğine göre "Az Tehlikeli" sınıfta yer almakta ve NACE kod sınıflandırılmasına göre 56- Yiyecek İçecek Hizmeti Faaliyetleri ana başlığı altında 
sınıflandırılmaktadır. Tehlike sınıfları iş sağlığı ve güvenliği ile ilgili yürütülecek faaliyetler açısından temel kriter olmakla birlikte, hazır yemek sektöründe faaliyet gösteren ișletme sayısı ve çalıșan sayısının fazla olması, esnek çalıșma saatleri, hafta sonu ve gece çalıșma zorunluluğu gibi sektörün kendine has yapısı nedeniyle tehlike sınıfından bağımsız olarak değerlendirilmesi gerekmektedir [7], [8]. Türkiye genelinde 2015 yılı itibariyle 4 bine yakın hazır yemek firması bulunmaktadır. Ayrıca sektör yıllık 6,5 milyar dolarlık iş hacmine sahiptir ve 400 bin kişiye doğrudan olmak üzere toplamda 1,5 milyon kişiye de istihdam sağlamaktadır [9].

İş kazaları çeşitli nedenlerden dolayı ortaya çıkabilmektedir. Çalışanların önemli bir etken olmasının yanı sıra çalışanın iş sağlığı ve güvenliğine bakış açısı ve güvenlik algısı da önem arz etmektedir. Bu araştırmada çalışanların kadercilik anlayışlarının iş sağlığı ve güvenliğine etkileri incelenmektedir. Kadercilik kavramı, ileride yaşanacakların önceden belirli olduğuna inanma, yaşananların kayıtsız kabulü ve öğrenilmiş çaresizlik olarak tanımlanmaktadır [10]. Kadercilik anlayışı, kişilerin hayatının ve toplumsal düzenin insanüstü bir güç tarafından önceden belirlendiği ve değiștirilmesinin mümkün olmadığı șeklinde tanımlanabilir [11].

Kader inancı ve kadercilik anlayışı neredeyse tüm inanç sistemlerinde var olmuştur [11]. Bireyler toplumsal yaşantılarında sahip oldukları kader anlayışı doğrultusunda tutum ve davranış sergilemektedirler. İş sağlığı ve güvenliği konusunda ise kişilerin risk ve önlem almadaki tutum ve davranışlarında kader anlayışının etkisi önemli bir yere sahiptir [11]. Yüksek düzeyde kader anlayışının risk almayı artırdığı, önlem almayı ise azalttığı görülmüştür [11]. Çalışanların işyerinde iş sağlığı ve güvenliğine yönelik ne yaparlarsa yapsınlar iş kazalarına engel olamayacakları algısı, işyerindeki iş sağlığı ve güvenliği uygulamaları ile işyerine ait iş sağlığı ve güvenliği kültürünü olumsuz etkileyeceği söylenilebilir [10]. Türk toplumunun kadercilik anlayıșı bakımından değerlendirilmesine yönelik yapılan bir araştırmada toplumun yaklaşık yarısı tarafından hayatın büyük çoğunluğunun kader ve doğaüstü güçler tarafından belirlendiği ve değiștirilemeyeceği sadece \% 28'lik bir kısmının ise hayatını değiștirebileceğine inandığı tespit edilmiştir [11].

Bu çalışmada hazır yemek sektöründe faaliyet gösteren işletmelerdeki çalışanların iş sağlı̆̆ ve güvenliğine kaderci bakış açılarının bazı demografik özelliklere ve çeşitli değişkenlere göre tespit edilmesi amaçlanmıştır.

\section{Materyal ve Metot}

\subsection{Materyal}

$\mathrm{Bu}$ araştırma Ankara ilinde faaliyet gösteren hazır yemek şirketlerinde çalışanların iş sağlığı ve güvenliğine kaderci bakış açılarının değerlendirilmesi amacıyla yürütüldü. Ankara ilinde hazır yemek sektöründe çalışanlar bu araştırmanın evrenini oluşturmaktadır. Araştırmanın örneklemini ise sektörde çalışanlardan tesadüfi örneklem yöntemi ile seçilen 8 farklı işletmede çalışan 160 kişi oluşturmaktadır.

\subsection{Metot}

Anket formu 3 bölüm ve 46 sorudan oluşmaktadır. İlk bölümde katılımcıların demografik bilgileri ve çalışma hayatına ait bilgiler; ikinci bölümde 3'lü Likert Ölçeği (Katılıyorum, kararsızım, katılmıyorum) kullanılarak çalışanın ve işyerinin iş sağlığı ve güvenliğine bakış açısının ölçülmesine yönelik önermeler; 3'ncü bölümde ise çalışanın iş sağlığı ve 
güvenliği konusundaki bilgi düzeyinin ölçülmesine yönelik 15 soru bulunmaktadır.

\section{3. İstatistiksel analiz}

Araştırma anketiyle elde edilen veriler SPSS v.22.0 istatistik paket programı ile analiz edilerek tablolar halinde yorumlandı. Katılımcılara ait demografik veriler frekans ve yüzde dağılımlarıyla birlikte tablolar halinde verildi. Çalışanların kadercilik anlayıșı ile bazı demografik özellikleri ve çeşitli değişkenler arasında istatistiksel olarak anlamlı olup olmadığı “Ki-kare Bağımsızlık Testi” ile yapıldı.

\section{Bulgular}

Çalışmada, katılımcılara ait demografik bilgiler Tablo-1'de gösterilmektedir. Buna göre, araştırmaya katılan çalışanların \% 63,1'inin erkek, \% 36,9'unun kadın olduğu belirlenmiştir. Yaş dağılımı itibariyle bakıldığında ise 26-40 yaş ve 41 yaşından büyük olanların çoğunlukta olduğu görülmektedir. Ayrıca katılımcıların büyük çoğunluğunun lise mezunu olduğu görülmektedir. Diğer yandan katılımclların ortalama mesleki deneyimine bakıldığında en az 1 yıl en fazla 40 yll olmak üzere ortalama 11 yıl tecrübeye sahip oldukları tespit edilmiştir. Son işyerindeki çalışma süresine bakıldığında en az 1 yıl en fazla 25 yıl olmak üzere ortalama çalışma süresinin 4 yıl olduğu belirlenmiştir. Diğer yandan araştırmaya katılanların \% 5'inin iş kazası geçirdiği tespit edilmiştir.

Tablo 1. Ankete katılan çalışanların demografik özellikleri

\begin{tabular}{|c|c|c|c|c|c|}
\hline Özellik & Sayı & Yüzdesi & Özellik & Sayı & Yüzdes \\
\hline Cinsiyet & & & Görev alanı & & \\
\hline Kadın & 59 & 36,9 & Üretim sorumlusu & 5 & 3,1 \\
\hline Erkek & 101 & 63,1 & Servis sorumlusu & 6 & 3,8 \\
\hline Yaş & & & Așçı\&Așçı yardımcısı & 46 & 28,7 \\
\hline 25 yaş altı & 10 & 6,3 & Kasap\&Tatlıcı\&Hamur ustası & 5 & 3,1 \\
\hline $26-40$ yaș arası & 72 & 45,0 & Bulaşıkçı\&Temizlikçi & 31 & 19,4 \\
\hline $\begin{array}{l}41 \text { yaşıından } \\
\text { büyük }\end{array}$ & 78 & 48,8 & $\begin{array}{l}\text { Garson\&Komi\&Servis } \\
\text { Elemanı }\end{array}$ & 40 & 25,0 \\
\hline Medeni durum & & & İdari Personel & 18 & 11,3 \\
\hline Evli & 115 & 71,9 & Şoför & 5 & 3,1 \\
\hline Bekâr & 26 & 16,3 & Diğer & 4 & 2,5 \\
\hline Diğer & 19 & 11,9 & Son İşyerindeki Çalıșma Süresi & & \\
\hline Eğitim Durumu & & & $1-5$ yll & 127 & 79,4 \\
\hline İlkokul & 44 & 27,5 & $6-10$ yll & 19 & 11,9 \\
\hline Ortaokul & 38 & 23,8 & $11-15$ yll & 5 & 3,1 \\
\hline Lise & 48 & 30,0 & 16 yıldan fazla & 9 & 5,6 \\
\hline Ön lisans & 8 & 5,0 & İş Kazası Geçirme Durumu & & \\
\hline Lisans & 17 & 10,6 & Evet & 8 & 5,0 \\
\hline $\begin{array}{l}\text { Yüksek lisans ve } \\
\text { üstü }\end{array}$ & 5 & 3,1 & Hayır & 152 & 95,0 \\
\hline Toplam Mesleki & & & Son İşyerinde İş Kazası & & \\
\hline Deneyim & & & Geçirme Durumu & & \\
\hline $1-5$ yll & 59 & 36,9 & Evet & 3 & 1,9 \\
\hline 6-10 yıl & 40 & 25,0 & Hayır & 157 & 98,1 \\
\hline $11-15$ yll & 30 & 18,8 & & & \\
\hline 16 yıldan fazla & 31 & 19,4 & & & \\
\hline
\end{tabular}


Katılımcılara anketin 2'nci bölümünde "Ne yaparsam yapayım iş kazasını engelleyemem" șeklinde bir önerme yöneltilmiş ve bu önermeye "Katılıyorum" șeklinde cevap verenlerin Kadercilik anlayışının pozitif, "Katılmıyorum" şeklinde cevap verenlerin ise negatif olduğu değerlendirilmiștir. Çalıșma sonucunda katılımcıların \%45,6'sı "Katılmıyorum", \% 31,9'u ise "Katılıyorum" șeklinde cevap vermiștir. Katılımcıların \% 22,5'i "Kararsızım" şeklinde cevap vermiştir. Tablo-2 demografik özellikler ve bazı çeşitli değişkenler ile çalışanların kadercilik anlayışları arasındaki ilişkileri açıklamaktadır.

Tablo 2. Demografik özellikler ve çeşitli değiş̧kenler ile kadercilik anlayışı arasındaki ilișkiler

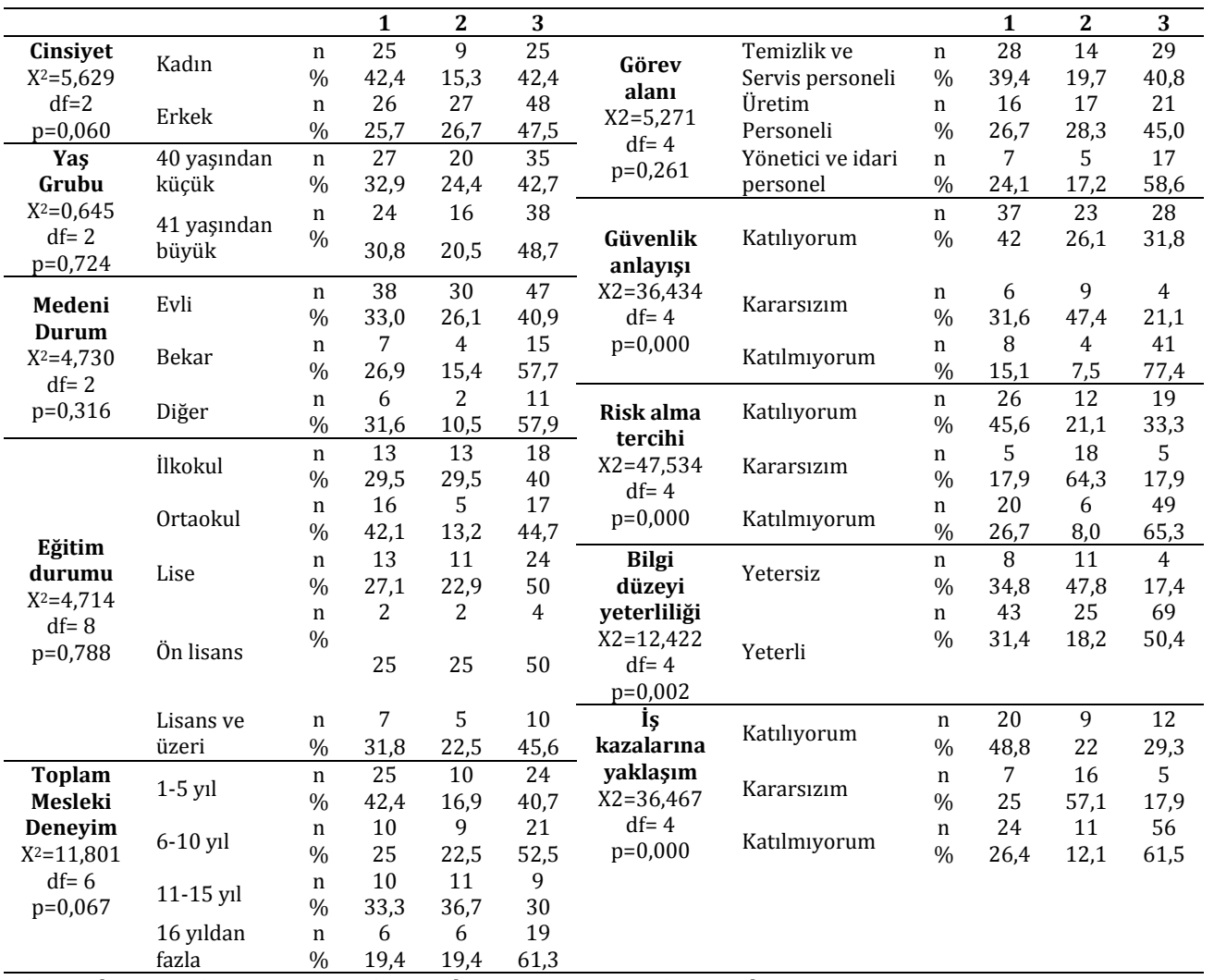

1= Katılıyorum, 2 = Kararsızım, 3 = Katılmıyorum, n= sayı, \%= yüzde oranı

Çalışanların demografik özellikleri ile çeşitli değiş̧kenler arasındaki ilişkiyi belirlemek amacıyla ki-kare analizi yapılmıştır. Yapılan 10 adet ki-kare testi sonucunda 4 ilişkinin istatistiksel olarak anlamlı $(\mathrm{p}<0,05), 2$ ilişkinin istatistiksel olarak sınırda anlamlı $(0,05<p<0,10)$ ve 4 ilişkinin ise istatistiksel olarak anlamsız olduğu $(p>0,10)$ tespit edilmiştir.

Katılımcıların cinsiyetleri ile kadercilik anlayışları arasındaki ilişkinin istatistiksel olarak sınırlı anlamlı olduğu sonucuna varılmıștır $(p=0,060)$. Cinsiyet değişkeni ile kadercilik anlayışının istatistiksel olarak anlamlılık eğiliminde olduğu ve katılımcl sayısının artırılması ile istatistiksel olarak anlamlılığın elde edileceği değerlendirilmektedir. Kadın katılımcılarda kadercilik pozitif anlayışı \% 42,4 iken erkeklerde \% 25,7'dir. Bu nedenle kadınların erkeklere oranla daha kaderci bir yaklaşım sergilediği değerlendirilebilir. Erkek katılımcıların "kararsızım" şeklinde verdikleri cevabın \% 26,7 oranında olması 
önermeye cevap vermek istemedikleri şeklinde yorumlanmıştır. Bu oranın yüksek olmasının ilişki analizinin sınırlı anlamlı çıkmasına neden olduğu değerlendirilmektedir.

Toplam mesleki deneyim ile kadercilik anlayıșı arasındaki ilişki istatistiksel olarak sınırlı anlamlı bulunmuștur ( $\mathrm{p}=0,067)$. Mesleki deneyim ile kadercilik anlayıșının istatistiksel olarak sınırlı anlamlılık eğiliminde olduğu ve önermeye kararsızım șeklinde cevap verenlerin oranının yüksek olması nedeniyle bu sonuca ulaşıldığı değerlendirilmektedir.

Güvenlik anlayışı ile kadercilik anlayışı arasındaki ilişki istatistiksel olarak anlamlı olarak tespit edilmiştir $(\mathrm{p}=0,000)$. Güvenlik anlayışının tespiti için çalışanlara Tablo-3'te bulunan "İsyerimde ișlerin en kısa yoldan yapılması esastır" önermesi yöneltilmiștir. Önermede beklenen cevap "katılmıyorum" olmasına rağmen katılımcıların \% 55'i "Katılıyorum" șeklinde cevap vermiştir. Yapılan ki-kare testi sonucunda kaderci yaklaşım sergileyenlerin \% 72,5'inin güvenlik anlayışının negatif yönde olduğu tespit edilmiștir. Güvenlik anlayışı negatif olanların \%63,9'u kaderci yaklaşım önermesinde "Kararsızım" şeklinde cevap vermiştir.

Risk alma tercihinin belirlenmesi amaciyla Tablo-3'te bulunan “İşimi yaparken risk almaktan kaçınmam" önermesi yöneltilmiştir. Önermede beklenen cevap "Katılmıyorum"'dur ve katılımcıların \% 46,9'u beklenen cevabı vermiştir. Yapılan ki-kare testi sonucunda Risk alma tercihi ile kadercilik anlayışı arasında istatistiksel olarak anlamlı bir ilişki olduğu tespit edilmiştir $(\mathrm{p}=0,000)$.

Katılımcılara anketin üçüncü bölümünde iş sağlığı ve güvenliği temel bilgi düzeylerinin ölçülmesi amacıyla 15 soru yöneltilmiş ve vermiş oldukları doğru cevap sayılarına 0-100 puan aralığında derecelendirilmiştir. Katılımcıların bilgi seviyeleri çok zayıf $(0,00-39,99)$, zaylf $(40,00-59,99)$, orta $(60,00-74,99)$, iyi $(75,00-89,99)$ ve çok iyi $(90,00-100,00)$ olarak gruplandırılmıștır. Anket sonucunda katılımcıların bilgi seviyelerinin \% 43,1'i orta, $\%$ 33,1'i iyi, \% 12,5'i zayıf, \%9,4'ü çok iyi ve \% 1,9'u çok zayıf şeklinde olmak üzere ortalama seviyenin orta olduğu tespit edilmiștir. Bilgi seviyesi çok zayıf ve zayıf olanların bilgi düzeyi yetersiz, orta, iyi ve çok iyi olanların ise bilgi düzeyi yeterli olarak belirlenmiştir. Yapılan bu sınıflandırma sonucunda katılımcıların \% 85,6'sının bilgi düzeyinin yeterli olduğu tespit edilmiștir. Kadercilik anlayıșı ile bilgi düzeyi yeterliliği arasında ilişkinin yapılan ki-kare testi sonucunda istatistiksel olarak anlamlı olduğu tespit edilmiștir $(\mathrm{p}=0,002)$.

Katılımcılara anketin 2'nci bölümünde yöneltilen ve sonuçları Tablo-3'te bulunan önermeler incelendiğinde 5 önermenin 4'ünde beklenen cevapların anket sonucu gözlenen değerlerle örtüştüğü, bir önermede ise beklenen cevabın alınamadığı görülmektedir. "Ne yaparsam yapayım iş kazalarını engelleyemem" önermesiyle çalışanın kaderci yaklaşımı tespit edilirken, "İşyerim iş kazaları işin doğal bir parçası olarak görülür ve hoş karşılanır" önermesiyle işletmenin kaderci yaklaşımı değerlendirilmiştir. Önermeye katılımcıların \% 56,9'u beklendiği şekilde "Katılmıyorum" şeklinde cevap vermiștir. Çalışanın kaderci yaklaşımı ile işletmenin kaderci yaklaşımı arasındaki ilişkinin tespiti için yapılan ki-kare testi sonucunda her iki kaderci yaklaşım arasında istatistiksel olarak anlamlı bir ilişki olduğu tespit edilmiştir $(\mathrm{p}=0,000)$. Benzer şekilde "Tehlikeli durumlarda risk almamam yöneticilerim tarafından hoş karşılanır" önermesi yönetimin iş sağlığı ve güvenliği konusundaki yaklaşımını göstermektedir. Bu önermede çalışanların \% 51,9'u "Katılıyorum" şeklinde cevap vererek beklenen cevabı vermişlerdir.

Tablo 3. Katılımcıların kadercilikle ilgili önermelere verdikleri cevapların dağılımı 


\begin{tabular}{|c|c|c|c|c|c|c|}
\hline \multirow[t]{2}{*}{ Önerme } & \multicolumn{2}{|c|}{ Katılıyorum } & \multicolumn{2}{|c|}{ Kararsızım } & \multicolumn{2}{|c|}{ Katılmıyorum } \\
\hline & Sayı & Yüzdesi & Sayı & Yüzdesi & Sayl & Yüzdesi \\
\hline $\begin{array}{l}\text { Kadercilik yaklaşımı-Ne yaparsam } \\
\text { yapayım iş kazalarını engelleyemem }\end{array}$ & 51 & 31,9 & 36 & 22,5 & $73^{*}$ & $45,6^{* *}$ \\
\hline $\begin{array}{l}\text { Güvenlik anlayışı-İsyerimde işlerin en } \\
\text { kısa yoldan yapılması esastır }\end{array}$ & 88 & $55,0^{* *}$ & 19 & 11,9 & $53^{*}$ & 33,1 \\
\hline $\begin{array}{l}\text { Risk alma Tercihi-İșimi yaparken risk } \\
\text { almaktan kaçınmam } \\
\text { İș Kazalarına Yaklaşım-İssyerimde iș }\end{array}$ & 57 & 35,6 & 28 & 17,5 & $75^{*}$ & $46,9^{* *}$ \\
\hline $\begin{array}{l}\text { kazaları işin doğal bir parçası olarak } \\
\text { görülür ve hoş karşılanır }\end{array}$ & 41 & 25,6 & 28 & 17,5 & $91 *$ & 56,9 ** \\
\hline $\begin{array}{l}\text { İşletme Yaklaşımı-Tehlikeli durumlarda } \\
\text { risk almamam yöneticilerim tarafından } \\
\text { hoș karșılanır }\end{array}$ & $83^{*}$ & $51,9^{* *}$ & 32 & 20,0 & 45 & 28,1 \\
\hline
\end{tabular}

Ayrıca yapılan ki-kare testi sonucunda kaderci yaklaşımla, yaş grubu, medeni durum, eğitim durumu ve görev alanı arasında istatistiksel olarak anlamlılık tespit edilememiştir.

Katılımcıların \% 5,0'i (8 kişi) meslek hayatı boyunca iş kazası geçirmiş, \% 5,6'sı (9 kişi) ramak kala olayla karşı karşıya kaldıklarını belirtmişlerdir. İş kazası geçirenlerin ve ramak olayı yaşayanların sayılarının istatistiksel analiz yapılmasına yeterli olmaması nedeniyle ki-kare testi uygulanmamıştır. İş kazası geçiren 8 kişiden 2'si son çalıştığı işyerinde iş kazası geçirmiş ve iş kazası sonucu çalışanların işten ayrı kalma süreleri en az 1 gün, en fazla 60 gün ve ortalama 23 gündür. İş kazası geçirenler demografik verilerine göre incelendiğinde; cinsiyetlerine göre 6'sı erkek, 2'si kadın çalışan, eğitim durumlarına göre; 1'i ilkokul, 2'si ortaokul ve 5'i lise mezunu, görev alanlarına göre ise; 2'si üretim Aşçı\&aşçı yardımcısı, 1'i bulaşıkçı\&temizlikçi, 2'si garson\&komi\&servis elemanı ve 3'ü ise şoför ve idari personeldir. Ramak kala olayı yaşayan 9 çalışandan 1 kişinin daha önce iş kazası geçirdiği tespit edilmiştir.

\section{Tartışma}

İş sağlığı ve güvenliği konusundaki önceki çalışmaların inşaat, maden gibi riskli alanlar başta olmak üzere birçok alanda yapıldığı görülmektedir. Sektör bazında hazır yemek alanında çeșitli çalıșmalar bulunmasına rağmen sektörde çalıșanların iș sağllğı ve güvenliğine kaderci bakış açılarına yönelik bir araştırmaya rastlanılmamıştır. İnsanların ileride karşılaşabileceği olayları değiştiremeyeceğine inanması kadercilik iken işyerinde karşılaşabileceği risklerden kaynaklı kazaların kaçınılmaz olduğuna inanması ise çalışma ortamında kadercilik yaklaşımı olarak değerlendirilmiştir.

Araştırmaya katılan çalışanların büyük çoğunluğu (\% 63,1) erkektir. Jeong (2015) [12], Eren ve ark. (2017) [13], Üner (2019) [14] ve Demirel (2009) [15] tarafindan yapılan çalışmalarda da erkek çalışanların çoğunlukta olması (sırasıyla \% 80, \% 88,6, \% 58 ve \%69) hazır yemek sektöründe erkek egemen bir çalışma ortamının bulunduğunu göstermektedir. Ayrıca SGK 2017 ve 2018 yılları verilerine göre tüm sektörlerde çalışanların \% 70'ini erkekler oluşturmaktadır [6]. Yapılan ki-kare testi sonucunda kadın çalışanların kadercilik anlayışlarının $(\% 42,4)$ erkek çalışanlardan daha yüksek olduğu tespit edilmiştir. Atan ve ark. (2017) [1] ve Dursun (2011) [16] tarafından yapılan çalışma sonucunda da kadınların erkeklere oranla kaderci yaklaşım sergilediği belirlenmiş olup kadınların kadercilik anlayışlarının yüksek oluşu her iki çalışma neticesinde ortaya konulmuştur. Kadın çalışanların kadercilik anlayışlarının yüksek olması verilecek olan eğitimlerde sektörde sayıca az olan kadınların kaderci bakış 
açılarını değiştirebilecektir.

Katılımcıların yaș gruplarına bakıldığında en küçük çalıșanın 18, en büyük çalıșanın ise 63 olduğu ve çalıșanların yaș ortalamasının 40,70 olduğu tespit edilmiștir. Ayrıca çalıșanların \% 48,8'inin 41 yașından büyük olduğu, \% 45'inin ise 26-40 yaș arasında olduğu tespit edilmiștir. Üner ve Ayberk (2019) [14] ve Eren ve ark. (2017) [13] tarafından yapılan çalıșmalarda benzer sonuçlar (sırasıyla, 31 yaș üzeri \%60,5; 18-40 yaș arası çalıșan \% 95) elde edilmiștir. Yapılan ki-kare testinde çalıșanların yașları ile kadercilik anlayıșı arasında istatistiksel olarak anlamlı bir ilișki tespit edilmemiș olup sektör farkı olmasına rağmen Aydın ve Ceylan (2020) [17]'da benzer șekilde anlamlı bir ilișki olmadığı sonucunu elde etmiștir. Atan ve ark. (2017) [1] tarafından yapılan çalışmada ise en yüksek kaderci olan yaş grubunun 35-54 yaş arası olduğu ve en düşük kaderci yaklaşım sergileyen yaş grubunun ise 18-24 yaş arası olduğu tespit edilmiştir.

Katılımcıların \% 71,9'u evli, \% 16,3'ü ise bekârdır. Yapılan ki-kare testi sonucunda kaderci yaklaşım ile medeni durum arasında istatistiksel olarak anlamlı bir ilişki tespit edilememiştir. Acar ve Kılıç (2019) [18] yaptıkları çalışmada katılımcıların güvenlik iklimi ile medeni durumları arasında anlamlı bir ilişki olmadığı sonucuna ulaşmıștır. Ancak Yıldız ve Yılmaz (2017) [19] inşaat sektöründe yaptıkları araştırmada evli çalışanların kaderci yaklaşımlarının bekâr çalışanlara göre daha yüksek olduğu sonucunu elde etmiştir.

Katılımcıların eğitim seviyelerine bakıldığında \% 51,2'sinin ilköğretim, \% 30'unun ise lise mezunu, yüksek okul ve üniversite mezunu olanların ise \% 18,8 olduğu tespit edilmiştir. Görev alanlarına göre eğitim seviyelerinde ise Temizlik ve servis personelinin \% 39,4'ü ilkokul ve \% 29,6'sı ortaokul olmak üzere \% 69'unun ilköğretim mezunu, Üretim personelinin \% 46,7'sinin lise mezunu ve yönetici ve idari personelin ise \% 65,5'inin yüksekokul ve üniversite mezunu olduğu tespit edilmiștir. Bindu ve Reddy (2015) [20], Üner (2019) [21], Eren ve ark. (2017) [13] ve Kabacık (2013) [22] tarafindan yapılan çalışmalarda da çalışanların eğitim seviyeleri (sırasıyla; \%55,5'i ilkokul, \%74,5'i ilkokul, ortaokul, lise, \%51,4'ünün ilköğretim, \% 42,1'i lise mezunu ve \% 32,6'sı ilkokul, \% 20,2'si ortaokul, \% 43,5'i lise mezunu) benzer șekildedir.

Bu nedenle iş sağlığı ve güvenliği anlamında daha fazla tehlikeye maruz kalan çalıșanların eğitim seviyesi de göz önüne alınarak verilen eğitimlerin güncellenmesi, özellikle düşük eğitim seviyesine sahip çalıșanlar tarafından da anlașılır hale getirilmesi gerekmektedir. Yapılan ki-kare testi sonucunda eğitim durumu ile kaderci yaklaşım arasında istatistiksel olarak anlamlı bir ilișki tespit edilmemiștir. Aydın ve Ceylan (2020) [17] tarafından orman ürünleri sanayinde çalışanların eğitim durumu ile kaderci yaklaşımları arasında istatistiksel olarak anlamlı bir ilișki tespit edilmiștir. Benzer șekilde Yıldız ve Yılmaz (2017) [19] inșaat sektöründe çalıșanların eğitim seviyeleri ile kadercilik anlayıșı arasında istatistiksel olarak anlamlı bir ilişki olduğunu tespit etmiştir. Atan ve ark. (2017) [1] yaptıkları araştırma sonucunda en yüksek kaderci olan grubun eğitim seviyesi yüksek lisans/doktora olanlar olduğunu, en düşük kaderci olan grubun ise lise mezunu olanlar olduğunu tespit etmişlerdir.

Hazır yemek sektörü emek yoğun bir sektördür. Çalışanların yaptıkları işlere göre üretim personeli, servis ve temizlik personeli ve yönetici ve idari personel olarak 3 ana başlık altında toplamak mümkündür. Araştırmada katılımcıların \% 44,4'ü temizlik ve servis personeli, \% 37,5'i Üretim personeli olarak ve \% 18,1'i yönetici ve idari personel olarak görev yapmaktadır. Yapılan ki-kare testi sonucunda görev alanı ile kadercilik yaklaşımı arasında istatistiksel olarak anlamlı ilişki olmadığı tespit edilmiştir. Benzer şekilde, Atan 
ve ark. (2017) [1] yaptıkları çalışmada katılımcıları yönetici ve çalışan olarak gruplandırmış ve görev alanı ile kadercilik yaklaşımı arasında istatistiksel olarak anlamlı bir ilişki olmadığı sonucuna ulaşmışlardır.

Katılımcıların \% 36,9'u (59 kişi) 1-5 yıl arasında mesleki tecrübeye sahip olup 16 yıl ve üzerinde toplam mesleki tecrübesi olanların oranı \% 19,4'tür (31 kiși). Aynı șekilde Eren ve ark. (2017) [1] tarafından yapılan çalıșmada da 1-5 yıl arası tecrübeye sahip kișilerin çoğunlukta $(\% 37,1)$ olması hazır yemek sektöründe iş değiştirmenin sık yaşandığı göstermektedir. Ayrıca katılımcıların \% 79,4'ünün son işyerindeki çalıșma süresi 1-5 yıldır. Yaș gruplarına göre belirli bir tecrübeye ulaștığı ve daha az iș değișikliği yapması beklenen 41 yaș ve üzeri katılımclların \% 75,6'sının son ișyerinde çalıșma süresi 1-5 yıldır. Atan ve ark. (2017) [1] tarafından sektör farkı gözetmeksizin tüm Türkiye'yi temsil edecek șekilde 12 ilde 2018 kişi üzerinde yapılan araștırma sonucunda son işyerinde çalışma süresi katılımcıların \% 55'inde 5 yıldan az olarak tespit edilmiștir. Elde ettiğimiz sonuç diğer çalıșmalarla benzerlik göstermekle birlikte hazır yemek sektöründe çalışanların sık iş değiștirme nedenleri arasında çalışan tecrübesinin mesleki ve maddi bir karşılığının olmaması bulunmaktadır. Aşçı, kasap, tatlı ustası gibi özellik arz eden görev alanı haricindeki görevler için mesleki tecrübenin işveren açısından önemi bulunmamakta ve tecrübeyle doğru orantılı olması beklenen maaş karşılığının çalışana sağlanmasından imtina edilmektedir. Çalışanlar tecrübe arttıkça beklenen maddi karşılığı elde edememeleri nedeniyle iş değişikliğine başvurmaktadırlar. Son işyerindeki çalışma süresinin kısa olmasının bir diğer nedeni ise hazır yemek hizmetinin özellikle üniversiteler, hastaneler ve Türk Silahlı Kuvvetleri gibi kamu kurumları, tarafından belirli bir süreyi kapsayacak șekilde sağlanmasıdır. İhale veya proje șeklinde yürütülen hazır yemek hizmetleri nedeniyle hazır yemek şirketlerin çalışan sayıları ihale ve proje bazlı olarak ciddi oranlarda değișmektedir. Bu nedenle de proje veya ihalenin el değiștirmesi durumunda çalışanlarında büyük çoğunluğu görev yeri ve görev alanı aynı kalmasına rağmen şirket değiştirmek zorunda kalmaktadır. Bu nedenle sektörde iş değișiklikleri çok sık yaşanmaktadır.

Yapılan ki-kare testi sonucunda mesleki deneyim ile kadercilik anlayıșı arasında sınırda anlamlı bir ilișki olduğu tespit edilmiș ve yüksek oranda $(\% 42,4)$ kaderci yaklașım sergileyenlerin 1-5 yıl arasında tecrübeye sahip olanlar, en düșük ise $(\% 19,4) 16$ yıldan fazla mesleki tecrübeye sahip olanlarda olduğu tespit edilmiștir. 6-10 yll tecrübeye sahip olanların \% 25,0'i, 11-15 yıl arası tecrübeye sahip olanların ise \% 33,3'ünün kaderci yaklaşım sergilediği tespit edilmiștir. 11-15 yll tecrübeye sahip çalıșanlar haricinde, kaderci yaklaşım mesleki tecrübe arttıkça azalır şeklinde yorumlanabilir. Ayrıca 11-15 yıl tecrübeye sahip olan katılımcıların \% 36,7'si "kararsızım" șeklinde cevaplayarak önermeyi cevaplamaktan kaçınmıșlardır.

Çalışmada katılımcıların iş sağlığı ve güvenliği bilgi düzeyi belirlenmiş ve \% 85,6'sının yeterli olduğu tespit edilmiştir. Sormaz ve ark. (2014) [3], yaptıkları çalışmada katılımcıların \% 18,6'sının sorulan 10 sorudan 6 ve daha fazlasına doğru cevap verdiklerini tespit etmișlerdir. Katılımcıların bilgi düzeylerine göre kadercilik yaklaşımları incelendiğinde istatistiksel olarak anlamlı bir ilişki olduğu tespit edilmiştir. Yapılan ki-kare testi sonucunda bilgi düzeyi yeterli olan katılımcıların kaderci yaklaşımlarının, bilgi düzeyi yetersiz olanlara göre daha düşük olduğu tespit edilmiştir. Ayrıca bilgi düzeyi yetersiz olarak değerlendirilen katılımcıların \% 47,8'i "kararsızım" şeklinde cevap vererek önermeyi cevaplamaktan kaçınmışlardır. Elde edilen sonuçlar iş sağlığı ve güvenliği konusunda verilecek eğitimlerin önemini ortaya koymaktadır. İnsanların ileride karşılaşabileceği olayları değiștiremeyeceğine inanması kadercilik iken işyerinde karşılaşabileceği risklerden kaynaklı kazaların kaçınılmaz olduğuna inanması 
ise çalışma ortamında kadercilik yaklaşımı olarak değerlendirilmiștir. Kaderci yaklașım kişilerin dini inançları, yetiștirilme tarzları gibi birçok nedenden kaynaklanabiliyor olmakla birlikte verilen eğitimle değiștirilebilir bir yaklașım olduğu görülmektedir. Araștırma sonucunda çeșitli demografik veriyle ilișkisini incelediğimiz yaklașımın çalıșanın eğitilmesi ile değiștirilebilir olduğu ve çalıșanlara verilecek eğitimlerin çalıșanın cinsiyet, eğitim durumu, medeni durum gibi özelliklerine göre dizayn edilmesi gerekmektedir. İs sağlığı ve güvenliği eğitimleri, çalıșanların demografik özellikleri dikkate alınarak içerik ve tekrar sıklığı belirlenmeli ve kadercilik yaklașımının en aza indirilmesi hedeflenmelidir.

Katılımcıların \% 5'i iş kazası geçirdiğini beyan etmiştir. İş kazası geçirenlerin 6'sı erkek, 2'si kadın olmak üzere toplam 8 kişidir. Atan ve ark. (2017) [1] yaptıkları araștırmada çalışanların \% 84,7'sinin iş kazası geçirdiği tespit edilmiştir. SGK 2018 yılına ait verilerde kadınların iș kazası geçirme oranı Yiyecek ve İçecek Hizmeti Faaliyeti sektöründe \% 34,7 iken tüm sektörlere bakıldığında \% 17,8'dir [6]. Araștırma sonucunda Yiyecek ve İçecek Hizmeti Faaliyeti sektörüne yakın bir oran elde edilmiștir. İș kazaları sonucu ișyerinden ayrı kalınan süreler incelendiğinde en az 1 gün, en fazla 60 gün olmak üzere çalıșanların ortalama 23 gün işyerinden ayrı kaldığı tespit edilmiştir. Atan ve ark. (2017) [1] yapmış oldukları çalışmada iş kazası geçirenlerin \% 71,4'ü işyerinden ayrı kalma süresini 30 günden az olarak belirtmişlerdir.

Araştırma sonucunda "İşyerimde işlerin en kısa yoldan yapılması esastır" șeklindeki önermeye katılımcıların \% 55'inin "Katılıyorum" şeklinde cevap verdikleri görülmektedir. $\mathrm{Bu}$ önerme için beklenen cevap katılımcıların büyük çoğunluğundan alınamamıștır. Bilindiği üzere işlerin yapılmasında en kısa yol çoğu zaman en güvenli yol değildir. Aslında verilen bu cevapla çalışanlar, tembellik, iş çokluğu veya zaman yetersizliği gibi nedenleri gerekçe göstererek güvenli yolu terk ettiklerini ve işin yapılmasına odaklandıklarını beyan etmişlerdir. Çalıșanlara verilen eğitimlerde bu konunun tekrar hatırlatılmasının uygun olacağı değerlendirilmektedir. Katılımcıların güvenlik anlayışları ile kaderci yaklaşımları arasındaki ilișkinin incelenmesi sonucunda güvenlik anlayıșı ile kaderci yaklașım arasında istatistiksel olarak anlamlı bir ilișki olduğu tespit edilmiștir. Çalışanların işin yapılması esnasında önceliklerinin güvenlik olduğu verilen eğitimlerde hatırlatılmalıdır. Ayrıca çalışanlar arasında kaderci yaklaşımın azalmasının kișilerin güvenlik anlayıșlarının değișmesinde de etkili olacağı değerlendirilmektedir.

"İşimi yaparken risk almaktan kaçınmam" şeklindeki önermeye katılımcıların büyük çoğunluğu (\% 46,9) beklendiği șekilde "Katılmıyorum" șeklinde cevap vermișlerdir. Katılımcıların risk alma tercihi ile kaderci yaklașımları arasındaki ilişkiye bakıldı̆̆ında, yapılan ki-kare testi sonucunda istatistiksel olarak anlamlı bir ilișki olduğu tespit edilmiștir. Çalıșanların risk almaktan kaçınmamaları iș kazalarının olasılıklarını veya ramak kala olay yaşama olasılıklarını artırmaktadır. Kaderci yaklaşım sergileyen çalışanların risk alma konusunda da aynı yaklaşım içerisinde oldukları görülmektedir (\% 45,6). Bu nedenle çalışanların kaderci bakış açılarının değiştirilmesi ile yapmış oldukları işle ilgili risk almaktan kaçınacakları ve bunun doğal bir sonucu olarak iş kazalarının engellenebileceği veya azaltılabileceği değerlendirilmektedir.

Benzer șekilde "Tehlikeli durumlarda risk almamam yöneticilerim tarafından hoş karşılanır" ve "İşyerimde iş kazaları işin doğal bir parçası olarak görülür ve hoș karşılanır" önermeleri yönetimin iş sağlığı ve güvenliği konusundaki yaklaşımını göstermektedir. Bu önermelerde çalışanların çoğunluğundan beklenen cevap alınmıştır. İşletmede kazaların işin doğal bir parçası olarak görülmesi çalışanın kaderci yaklaşımını 
desteklemektedir. Çalıșan tarafından tehlikeli durumlarda risk almaması ise kazaların önüne geçecektir ancak risk alınmayan durumlarda ișlerin yapılma hızı etkilenecektir. Yöneticiler bu durumlarda çalıșanların güvenliğinin ișlerin yapılmasından önce geldiğini çalışanlara aktarabilmelidir. Çalışanın kaderci yaklaşımı ișletmenin yaklașımının göstergesidir ve ișletme yaklașımının değiștirilmesi ile çalıșanın kaderci yaklașımı değiștirilebilecektir. Bu nedenle ișletmede iș kazaları olağan karșılanmamalı mümkünse kaza olmadan eğer mümkün değil ise kazadan sonra tekrarlanmaması için tedbirler alınmalıdır. Ayrıca önermelerde "kararsızım" șeklinde verilen cevapların yaklașık \% 20 düzeyinde olduğu görülmektedir. Bu șekilde cevap verilen önermeler incelendiğinde işyerinin iş sağlığı ve güvenliği konusunda önlem alıp almadığının sorgulandığı önermeler olduğu ve anket sonuçlarının ileride yönetim tarafından incelenmesi durumunda zor durumda kalınacağı endișesi ile bu șekilde ișaretlendiği değerlendirilmektedir. Bu nedenle "Kararsızım" oranının yüksek olduğu sorularda istenmeyen durumun o işletmede veya çalışanda var olduğunu ancak beyan etmekten kaçındığını değerlendirmek mümkündür.

İş Sağlı̆̆ı ve güvenliği, işyerinde meydana gelebilecek kaza ve olaylardan korunmayı hedeflemekle birlikte çalışanların fiziksel ve ruhsal yaşantılarını da etkilemektedir. Önlemlerin alındığı ve güvenli bir çalışma ortamının yaratıldığı bir işletmede çalışmak çalışan açısından moral ve motivasyon kaynağı olacak ve bu bireylerin üretime olan katkıları artacaktır [3]. Hazır yemek sektörü insan gücü ağırlıklı bir sektördür [12]. Hazır yemek sektöründe üretimin yapıldığı alan mutfaktır ve mutfak en genel anlamıla yiyeceklerin hazırlandığı, kısa süreli depolandı̆̆ı ve pişirildiği alandır [23], [24]. Sektör "Az Tehlikeli" sınıfta olmasına rağmen gerek karşı karşıya kalınan riskler ve gerekse çalışan sayısının yüksek olması nedeniyle iş sağlığı ve güvenliği açısından yeterli önemin verilmesi gerekmektedir. Sektörde meydana gelen kaza sayısına göre ölüm oranı düşük olsa da sektörde iş sağlığı ve güvenliği ile ilgili tedbirlerin gözden geçirilmesi ve alınacak tedbirlerin artırılmasına yönelik tehlike sınıfının yeniden gözden geçirilmesinin uygun olacağı değerlendirilmektedir [6].

Çalışanların iş sağlığı ve güvenliği eğitimleri cinsiyet, eğitim durumu, yaş, görev alanı ve mesleki tecrübe gibi değișkenlere göre tasarlanmalı ve eğitimlerin içerik ve sıklıklarında bu veriler dikkate alınmalıdır. İşyerinde karşı karșıya kalınan tehlikeye ait riskin büyüklüğüyle çalıșanın kaderci yönelimi doğru orantılıdır. Çünkü tehlikeli durumlarda alınan önlemlerle ișin tam olarak güvenli hale getirilemediği durumlarda çaresizlik duygusu nedeniyle kadercilik anlayıșı öne çıkmaktadır [10]. Çalıșanların iș kazalarının kaderden kaynaklandığı ve bu nedenle engellenemeyeceği algısının değiștirilmesinin eğitimle mümkün olduğu ve bu nedenle verilecek eğitimlerde bu konu üzerinde hassasiyetle durulması sektör çalışanlarının daha güvenli hale gelmesini sağlayacaktır.

\section{Kaynaklar}

1. Murat A, Erdem C, Elif Ç, Berna AY, Deniz EB. Türkiye'de iş sağlığı ve güvenliği algısı. Ankara; 2017.

2. Bayraktaroğlu S, Aras M, Atay E. Çalıșanlarda iş güvenliği ve iş kazası algısı: Mavi yakalılar üzerine bir araștırma. Uluslararası Yönetim ve Sos Araștırmalar Dergisi [Erișim tarihi: 21 Ekim 2018]. 20 Ocak 2018;5(9):1-15. Erișim adresi: http://dergipark.gov.tr/uysad/issue/37764/436003

3. Sormaz Ü, Demirçivi BM, Yeșiltaş M. Dışarıya yemek hizmeti veren (Catering) ișletmelerde çalıșanların iș güvenliği bilgilerinin değerlendirilmesi. Aksaray Üniversitesi İktisadi ve İdari Bilim Fakültesi Dergisi [Erișim tarihi:06 Kasım 
2018]. 2014;6(2):61-76. Erişim adresi: http://dergipark.gov.tr/aksarayiibd/issue/22547/240957

4. 4857 sayılı iş kanunu. T.C. Resmi Gazete [Erişim tarihi: 06 Kasım 2018], 2003. Erișim adresi: https://www.resmigazete.gov.tr/eskiler/2003/06/20030610.htm

5. İş sağlığı ve güvenliği kanunu. T.C. Resmi Gazete [Erişim tarihi: 11 Kasım 2018], 2015. Erișim adresi: http://www.resmigazete.gov.tr/eskiler/2012/06/20120630-1.htm

6. SGK Yillık İstatistikleri. http://www.sgk.gov.tr/wps/portal/sgk/tr/kurumsal/istatistik/sgk_istatistik_yil liklari. [Erișim tarihi: 09 Kasım 2018]. Erișim adresi: http://www.sgk.gov.tr/wps/portal/sgk/tr/kurumsal/istatistik/sgk_istatistik_yil liklari

7. Özer S, Tüzünkan D, Köse BÇ. Turizm sektöründe iş kazaları ve meslek hastalıklarına yönelik tespitler ve tedbirler. 14 Turizm Kongresi. Kayseri; 2013. s. 1136-1149.

8. ̇ Is Sağlığı ve Güvenliğine İlişkin İşyeri Tehlike Sınıfları Tebliği. T.C. Resmi Gazete [Erişim tarihi: 13 Mayıs 2019], 2012. Erişim adresi: https://www.resmigazete.gov.tr/eskiler/2012/12/20121226.htm

9. Kaya K, Sevinç G, Sevinç MR, Asoğlu V. Hazır yemek işletmelerinin sorunları ve çözüm önerileri: Şanlıurfa örneği. Dicle Üniversitesi İktisadi ve İdari Bilim Fakültesi Dergisi. 2015;5(8):1-9.

10. Çalışkan BÖÖ, Tüzüner VL. Çalışanların kadercilik algılarının iş güvenliği endișelerine ilişkin algılarına etkisi: depo çalıșanları üzerinde bir araştırma. Kesit Akad Dergisi. 2019;18:60-70.

11. Akkuş Hİ, Taş K. Türkiye'de iş kazaları ve kader anlayışı üzerine tipolojik bir araştırma: iş kazaları ve kader ölçeği. Turkish Stud Relig Stud. 2019;14(4):591602.

12. Jeong BY. Cooking processes and occupational accidents in commercial restaurant kitchens. Safety Science [Erişim tarihi: 27 Ekim 2019]. 2015;80:8793. Erişim adresi: http://dx.doi.org/10.1016/j.ssci.2015.07.014

13. Eren R, Nebioğlu O, Şı A. Knowledge levels on food safety of employees working in hotel enterprises' kitchen: the example of Alanya. Journal Multidisciplinary Academic Tourism [Erișim tarihi: 29 Nisan 2020] 2017;2(1):47-64. Erișim adresi: http://dergipark.gov.tr/doi/10.31822/jomat.350175

14. Üner MH, Ayberk HS. Düzce ilindeki mutfak çalıșanlarının genel bilgileri ile kaza geçirme oranlarının incelenmesi. Düzce Üniversitesi Bilim ve Teknoloji Dergisi [Erişim tarihi: 29 Nisan 2020] 2019;7(1):861-71. Erişim adresi: http://dergipark.gov.tr/doi/10.29130/dubited.502022

15. Demirel S. Hazır yemek üretimi yapan işletmelerde çalışanların hijyen bilgi düzeylerinin belirlenmesi. Namık Kemal Üniversitesi; 2009.

16. Dursun S. Güvenlik kültürünün güvenlik performansı üzerine etkisine yönelik bir uygulama. Uludağ Üniversitesi; 2011.

17. Aydın A, Ceylan G. Orman ürünleri sanayi çalışanlarının iş sağlı̆̆g ve güvenliğine kaderci bakış açllarının tespit edilmesine yönelik bir araştırma. Düzce Üniversitesi Bilim ve Teknoloji Dergisi [Erişim tarihi: 29 Nisan 2020] 2020;8(1):1033-41. Erişim adresi: https://dergipark.org.tr/tr/doi/10.29130/dubited.652938

18. Acar P, Kılıç S. Güvenlik iklimi algısının demografik faktörlere göre alan kuramı bağlamında incelenmesi: inşaat sektöründe bir uygulama. Elektronik Sosyal Bilimler Dergisi [Erişim tarihi: 02 Mayıs 2020] 2019;18(71):1066-88. Erişim adresi: http://dergipark.org.tr/doi/10.17755/esosder.453410 
19. Yıldız S, Yılmaz M. Türk inşaat sektöründe çalışanların güvenlik kültürü düzeyinin ve güvenlik performansı ile ilișkisinin incelenmesi. Politeknik Dergisi [Erişim tarihi: 02 Mayıs 2020] 2017;20(1):137-49. Erişim adresi: https://dergipark.org.tr/tr/pub/politeknik/issue/36869/420511

20. Bindu ESH, Reddy M V. Occupational hazards among cooks in commercial kitchens. International Journal of Science and Research. 2013;5(6):970-4.

21. Üner MH. Düzce ilindeki mutfak çalıșanlarının iș güvenliği bilgi düzeylerinin saptanması ve kaza geçirme oranlarıyla karşılaştırılması. Okan Üniversitesi; 2019.

22. Kabacik M. Dört ve beș yıldızlı otel mutfaklarında çalıșan mutfak personelinin gıda güvenliği konusunda bilgi düzeylerinin saptanması. Ordu Üniversitesi Sosyal Bilimler Dergisi. 2013;7:112-20.

23. Doğdubay M, Karan İ. Otel mutfaklarında sistematik işyeri düzenleme planı (SIDP) modelinin uygulanması. Aydın Gastronomy. 2017;1(1):9-23.

24. Elle Taşıma İşleri Yönetmeliği. T.C. Resmi Gazete [Erişim tarihi: 21 Aralık 2018], 2013. Erişim

adresi:

https://www.resmigazete.gov.tr/eskiler/2013/07/20130724-24.htm 